\title{
Oxidative Stress by Tartrazine in the Testis of Wistar Rats
}

\author{
B. Visweswaran ${ }^{1}$ and G. Krishnamoorthy ${ }^{2 *}$ \\ ${ }^{1 \& 2}$ Department of Zoology, K. M. Centre for PG Studies, Pondicherry (Central) University, Lawspet Campus, \\ Puducherry - 605 008, India.
}

\begin{abstract}
The aim is to study the effect of Tartrazine (E102) - synthetic food colour - on the antioxidant status of testis of Wistar rats. Twelve male Wistar rats were grouped into 2 groups of six each-Control and Tartrazine-treated groups. Control group was orally administered with water alone while the experimental group was orally administered with tartrazine dissolved in water. The treatment was carried out for 60 days and the activities of antioxidant enzymes - superoxide dismutase (SOD), catalase (CAT), glutathione peroxidase $(G P x)$ and glutathione reductase $(G R)$ and the levels of their cofactors were subsequently determined in the testis, along with histological studies. Activities of the 4 enzymes showed a common decrease with corresponding alterations in their cofactor levels. The colour orally administered to the experimental animals probably would have generated reactive oxygen species (ROS) and $\mathrm{H}_{2} \mathrm{O}_{2}$, thereby disrupting the enzymatic antioxidant defense of their testes. Tartrazine is capable of producing free radicals, which in turn cause damage to the cellular compartment system of rat testis.
\end{abstract}

Keywords: Antioxidant enzymes, oxidative stress, tartrazine, testes

\section{INTRODUCTION}

Food colours are found to have an effect in the food choice by influencing taste, sweetness and pleasantness. Making the food products, many attractive types of natural and synthetic dyes were used. Comparatively, the synthetic food dyes are stable, less expensive and occupy an important place in food industry [1]. The most common artificial food colours were azo dyes that included the aromatic azo compounds, such as Tartrazine which is widely used. Tartrazine is an orange-coloured, water-soluble (E102 or FD \& C Yellow 5 or C.I. 19140) colour, principally, the trisodium 5-hydroxy-1-(4-sulfonatophenyl)-4(sulfanotophenylazo)-H-pyrazol-3-carboxylate.

Many products like soft drinks, flavoured chips, confectionery mixes, soups, sauces, ice cream, jam and jelly contain Tartrazine [2]. Children are mostly attracted towards the coloured foods especially sweets, beverages and confectioneries and are the major consumers of coloured foods. In a developing country like India, the indiscriminate use of food colours, during festival seasons, was above the acceptable daily intake (ADI), which in turn resulted in serious health hazards among the human beings [3]. The ingestion of Tartrazine had shown some behavioural changes among children such as irritability, restlessness, sleep disturbance [4][5]. Animal studies also have established the DNA-damaging (mutagenic) effect of Tartrazine [6].

The metabolite of Tartrazine can generate reactive oxygen species (ROS), which, in turn, accelerate the oxidative stress [7]. Tartrazine causes changes in kidney and liver biochemical profiles [8] and also becomes more risky at higher doses, inducing oxidative stress on tissue by free radical formation. Oxidative metabolism of cells is a continuous source of ROS, resulting from univalent reduction of $\mathrm{O}_{2}$ that can damage most cellular components, leading to cell death [9]. Antioxidant system is involved in the defense system against free radicalmediated tissue or cellular damage [10]. Considerable knowledge about the antioxidant insult by Tartrazine had not been documented so far. Hence, it is aimed to study the enzymatic antioxidant profiles - superoxide dismutase (SOD), catalase (CAT), glutathione peroxidase (GPx) and glutathione reductase (GR) of testes of tartrazine -treated rats.

\subsection{Chemicals}

\section{MATERIALS AND METHODS}

All the chemicals and reagents were obtained from Sigma chemical company [USA] and Sarabhai M chemicals [India]. Tartrazine was obtained from Roha Dyechem Pvt. Ltd., Maharashtra [India].

\subsection{Animals}

Twelve healthy adult male albino rats of Wistar strain [Rattus norvegicus] weighing $150-200 \mathrm{~g}$ of body weight and 90 days old were used. The rats were kept in clean polypropylene cages in a temperature controlled room with 12 hours light/dark schedule. They were fed with balanced diet with free access of water.

All the animal experiments were conducted according to the ethical norms approved by Ministry of Social Justices and Empowerment, Government of India, and Institutional Animal Ethical Committee 
guidelines. The rats were randomly divided into two groups of six each. Group-I included control rats that received water for 60 days. Group-II received Tartrazine dissolved in water $(72 \mathrm{mg} / \mathrm{kg}$ body weight/day) for 60 days.

On the $61^{\text {st }}$ day, they were sacrificed by decapitation. Testes of each animal were excised and used for histological and biochemical studies. A portion of each testis was fixed in $10 \%$ neutral buffered formalin for histopathology, and was further processed using standard method. The micro-sections of $5 \mu \mathrm{m}$ thicknesses were stained with haemotoxylin-eosin and the prepared slides were examined under light microscope.

The tissue extract was used for estimation of activities of SOD[11], CAT[12], GPx[13] and GR[14]. The testicular content of trace elements like copper $(\mathrm{Cu})$, zinc $(\mathrm{Zn})$, manganese $(\mathrm{Mn})$ and iron $(\mathrm{Fe})$ were also estimated after acid digestion, using Inductively Coupled Plasma - Optical Emission Spectrophotometer (ICPOES) (Make: Perkin Elmer Precisely; Model: Optima 2100DV). Data were arrived at as mean \pm SEM. The statistical significance was determined by Student's't' test.

\section{RESULTS}

The activities of antioxidant enzymes were measured in Tartrazine-treated rat testes and compared with that of control rats. Administration of tartrazine to rats for 60 days had significantly reduced the SOD and CAT activities $(\mathrm{P}<0.001)$ in testes (Fig.1). Similarly, GPx and GR, other enzymes of the antioxidant system were also found to be fluctuated $(\mathrm{P}<0.01)$ in tartrazine-treated rat testes (Fig.1).

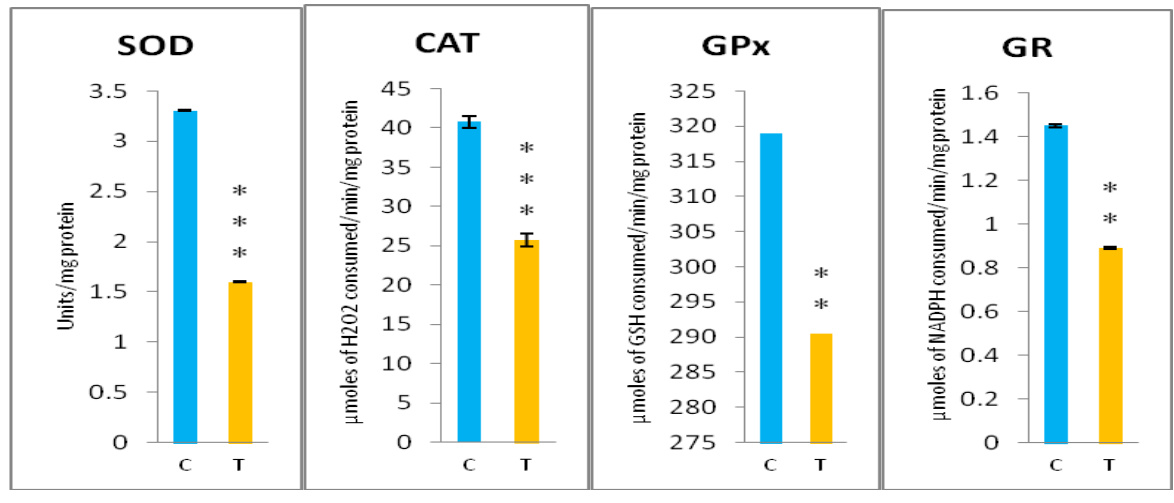

${ }^{* * *} \mathrm{P}<0.001=$ Control group $(\mathrm{C})$ Vs Tartrazine-treated group $(\mathrm{T})$

${ }^{* *} \mathrm{P}<0.01=$ Control group $(\mathrm{C})$ Vs Tartrazine-treated group $(\mathrm{T})$

Figure 1. Activity of Testicular Antioxidant Enzymes

In addition to antioxidant enzyme activities, the major cofactors of these enzymes $-\mathrm{Cu}, \mathrm{Zn}, \mathrm{Fe}$ and $\mathrm{Mn}$ - were also quantified in testicular tissues of control and tartrazine-treated rats. The content of $\mathrm{Cu}$ and $\mathrm{Zn}$ was less $(\mathrm{P}<0.001)$ in tartrazine-treated rat testes than in the control rat testes (Fig.2). Conversely, the $\mathrm{Fe}(\mathrm{P}<0.01)$ and $\mathrm{Mn}(\mathrm{P}<0.05)$ contents of testes of tartrazine-treated animals showed a significant rise, when compared to that of the control animals (Fig.2).

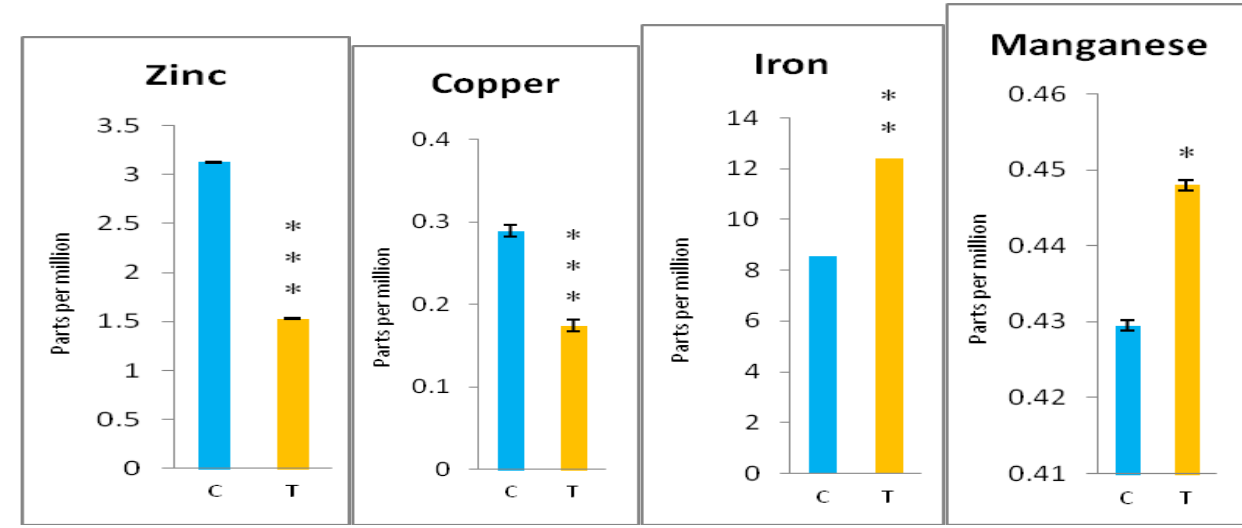

${ }^{* * *} \mathrm{P}<0.001=$ Control group $(\mathrm{C}) \mathrm{Vs}$ Tartrazine-treated group $(\mathrm{T})$

${ }^{* *} \mathrm{P}<0.01=$ Control group $(\mathrm{C}) \mathrm{Vs}$ Tartrazine-treated group $(\mathrm{T})$

${ }^{*} \mathrm{P}<0.05=$ Control group $(\mathrm{C})$ Vs Tartrazine-treated group $(\mathrm{T})$

Figure 2. Levels of Testicular Trace Elements 
Along with the enzyme activities and trace elements quantification, the light microscopic study was also attempted in the testes of these two groups. The systemic and well-differentiated seminiferous tubules and Leydig cells, with their regular orientation were noticed in control rat testes (Fig.3), whereas tartrazine administration had reduced the space in between seminiferous tubules, which resulted in shrunken and minimized Leydig cells (Fig.4). The regular and circular shape of seminiferous tubules and radial differentiation of their spermatogenic cells were also severely disturbed by the food dye treatment (Fig.4). Instead of circular shape, the tubules were ovally elongated and showed poorly differentiated spermatogenic cells (Fig.4). Further, the treatment resulted in narrowed intertubular space and reduced luminal space for spermatogenic products (Fig.4).

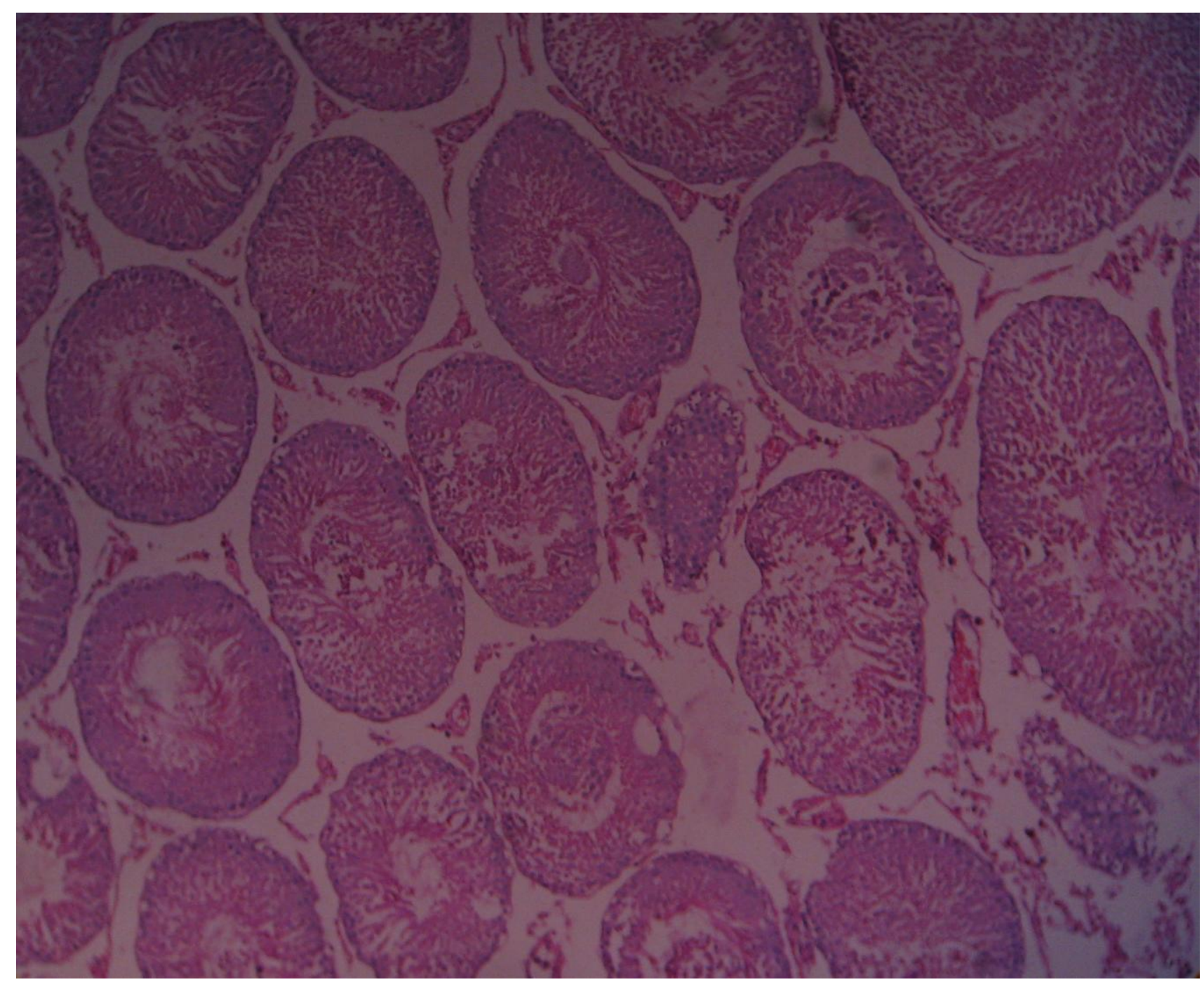

Figure 3 Testicular section from control rat (10x), showing circular shaped seminiferous tubules and Leydig cells 


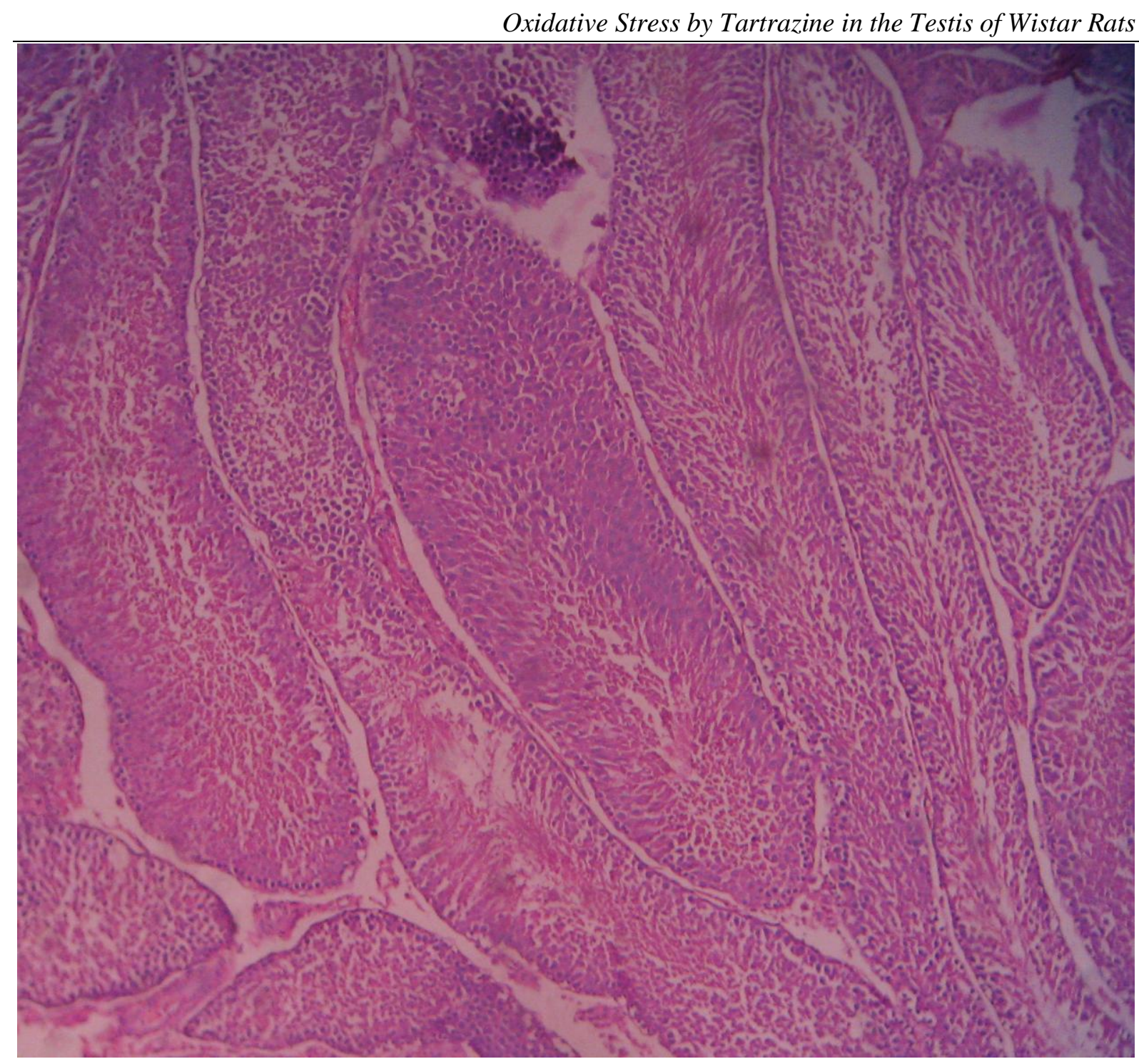

Figure 4 Testicular section from Tartrazine-treated rat (10x), showing elongated seminiferous tubules and rudimentary Leydig cells

\section{DISCUSSION}

Oral administration of Tartrazine, daily to male rats for sixty days of duration, suppressed the activities of antioxidant enzymes in testes. SOD, a primary free radical-scavenging antioxidant enzyme [15], which detoxifies superoxide $\left(\mathrm{O}_{2}^{-}\right)$, got critically reduced with its activity by this subchronic treatment. The influx of tartrazine and its metabolites might have caused the generation of free radicals like $\mathrm{H}_{2} \mathrm{O}_{2}$, which, in excess, would have inhibited the activity of SOD [16] in testes. To support our suggestion about food colour administration, a recent study has demonstrated the generation of ROS by food colours [8], which could induce oxidative stress. Our results are in accordance with recent reports that demonstrated the declined activities of antioxidant enzymes in liver [17] and brain [18] of tartrazine-treated rats. Production of ROS in an organism was correlated to the decreased levels of antioxidant enzymes, which results in oxidative stress [19]. The oxidative stress is due to the disruption of the equilibrium between production of free radicals and their being scavenged by the antioxidant system [20][21].

Excessive ROS production that exceeds critical levels can overwhelm all antioxidant defense strategies, causing oxidative stress [22]. . As a result of ROS formation, the antioxidant defense mechanism of the cells including SOD, CAT and GSH began to prevent the cell death by these toxic radicals so their levels in the tissue homogenate were decreased specially at higher doses [17]. The extent of oxidative stress-induced damage depends not only on the nature and amount of ROS involved but also on the moment and duration of ROS exposure and ROS scavengers [19].

Deficiencies of trace elements like $\mathrm{Zn}$ and $\mathrm{Cu}$ have been implicated with infertility [23]. The $\mathrm{Cu}, \mathrm{Fe}$, $\mathrm{Mn}$ and $\mathrm{Zn}$ are the integral parts of enzymatic antioxidants and they play important roles in the catalytic and antioxidant activities of major enzymes [24]. In the present study, an attempt was made to correlate the levels of 
$\mathrm{Cu}, \mathrm{Fe}, \mathrm{Mn}$ and $\mathrm{Zn}$ to that of the activities of antioxidant enzymes in the testicular tissues from control and tartrazine-treated animals. Interestingly, the levels of $\mathrm{Cu}$ and $\mathrm{Zn}$ in testes of experimental animals were reduced by tartrazine. The $\mathrm{Cu}$ and $\mathrm{Zn}$ are the metallic parts of $\mathrm{Cu}-\mathrm{Zn} \mathrm{SOD}$, catalyzing the dismutation of superoxide to $\mathrm{H}_{2} \mathrm{O}_{2}$, which must be removed by CAT and/or GPx. The observed reduction of $\mathrm{Cu}$ and $\mathrm{Zn}$ in tartrazine-treated testes would have decreased the activities of SOD [25].

Tartrazine seems to act as a zinc-chelating agent [26] and might have ended in the depletion of $\mathrm{Zn}$ in testes. Further, the reduction of $\mathrm{Zn}$ in tartrazine-treated animal tissue would have been due to increased urinary excretion of $\mathrm{Zn}$ by tartrazine [27]. The presence of $\mathrm{Zn}$ at the cellular level is essential for the cell growth and division in gonads, which occurs continuously [28]. Zn deficiency could seriously affect reproductive events in most species i.e. in male; it affects spermatogenic process [29]. Deficiency of Zn caused testicular atrophy and reductions in libido and sperm production and atrophy of seminiferous tubules and complete inhibition of spermatogenesis [30].

$\mathrm{Cu}$ deficiency results in an increase in $\mathrm{Fe}$, whereas an excess of $\mathrm{Cu}$ results in decrease in Fe utilization [31]. So, the reciprocal antagonism between $\mathrm{Cu}$ and $\mathrm{Fe}$ might be the reason for the increased $\mathrm{Fe}$ in the tartrazinetreated rats. $\mathrm{Zn}$ is a remarkable antioxidant [32], whose deficiency results in oxidative stress. Oxidative stress due to excessive production of ROS, impaired antioxidant defense mechanisms or both participate in the damage of testicular structure or the architecture of seminiferous tubules, which are believed to negatively affect the male reproductive function. All cellular components including lipids, proteins, nucleic acids and sugars are potential targets for oxidative stress. ROS can damage proteins, lipids and DNA, altering the organ structure and function. The membrane lipids contain unsaturated fatty acids, which are particularly susceptible to peroxidation. As the biological membranes are prone to the ROS effect, the peroxidation of unsaturated fatty acids in biological membranes leads to a decrease of membrane fluidity and disruption of membrane integrity and function, which is implicated in serious pathological changes [33]. Spermatozoa are particularly susceptible to oxidative stress-induced damage because their plasma membranes contain large quantities of polyunsaturated fatty acids [34] and their manchettes contain low concentration of scavenging enzymes [35]. Among the wellknown biological antioxidants, systems of SOD, CAT, GPx and GR have a significant role in protecting the spermatogenesis or sperm against peroxidative damage [35].

Superoxide, peroxide, hydroxyl radical and other free radicals derived from oxygen are highly reactive and threatening to the integrity of essential biomolecules such as DNA and RNA, proteins, enzymes and phospholipids, responsible for membrane integrity. One antioxidant role of CAT is to lower the risk of hydroxyl radical formation from $\mathrm{H}_{2} \mathrm{O}_{2}$, catalyzed by $\mathrm{Cu}$ or $\mathrm{Fe}$ ions. Minerals like $\mathrm{Mn}, \mathrm{Cu}$ and Zinc are involved in governing successful reproductive process [36]. The $\mathrm{Cu}$ and $\mathrm{Zn}$ are essential to destruct the free radicals through the cascading enzyme system [37].

Histological observation under light microscope, using eosin-haemotoxylin stain, clearly shows the defective architecture of seminiferous tubules within the testes of tartrazine-treated animals. The lumens of seminiferous tubules were also found to be reduced, indicating their compressed and bundled disorientation, whereas the same were radially oriented in control testes. Similarly, Mehedi et al. (2009) [38] demonstrated the histological damages in the seminiferous tubules and Leydig cells of tartrazine-treated mice. So, the altered architecture of seminiferous tubules in tartrazine group of animals is very well correlated to the damaged membrane proteins and lipids.

\section{CONCLUSION}

The present study concludes that Tartrazine initiates the Zn mobilization (by chelating action) from testis, which is essential for normal growth and functioning (spermatogenesis), and results in depression of antioxidant enzyme system. The oxidative stress caused by the imbalance of prooxidant and antioxidant system might have demorphed the testicular architecture. However, the findings and suggestions require further study on membrane structure to establish the damage caused by Tartrazine.

\section{Acknowledgement}

We are very grateful to the Director, K.M. Centre for PG Studies, Puducherry, India, for providing us the facilities to carry out this research work.

\section{REFERENCES}

[1] H Nayak and KG Nath, Dietary Intake of Synthetic Colours by School Children, Karnataka J Agric Sci, 20 (4), 2007, 819-822

[2] K Walton, R Walker,JJM Sandt and JV Castell, The application of in vitro data in the derivation of the acceptable daily intake of food additives, Food Chem Toxicol, 37 (12), 1999, 1175-1197.

[3] P Rao, RV Bhat, RV Sudershan and TP Krishna, Consumption of synthetic food colours during festivals in Hyderabad, India, British Food Journal, Vol 107, No 5, 2006, pp 276-284.

[4] KS Rowe and KJ Rowe, Synthetic food coloring and behavior: a dose response effect in a double-blind, placebo-controlled, repeated-measures study, J Pediatr, 125, 1994, 691-8.

[5] P Rao and RV Sudershan, Risk assessment of synthetic food colours: a case study in Hyderabad, India, Int.J.Food Safety Nutrition and Public Health, Vol 1, No 1, pages 68-87. 
[6] YF Sasaki, S Kawaguchi, A Kamaya, M Ohshita, K Kabasawa, K Iwama, K Taniguchi and Tsuda S, The comet assay with 8 mouse organs: results with 39 currently used food additives, Mutat. Res. 519 (1-2), 2002, 103-119.

[7] AK Bansal, Modulation of N-nitrosodiethylamine-induced oxidative stress by vitamin E in rat erythrocytes Human Exp Toxicol,24, 2005, 297-302.

[8] I Himri, S Bellachen, F Souna, F Belmekki, A Mohammed, B Mohamed, J Zoheir, Z Berkia, H Mekhfi and E Saalaoui, A 90-day Oral Toxicity Study of Tartrazine, a Synthetic Food Dye, in Wistar Rats, Int J Pharm Pharm Sci, Vol 3, Suppl 3, 2011, 159-169.

[9] AE Morales, A Pe'rez-Jime'nez, MC Hidalgo, E Abella and G Cardenete, Oxidative stress and antioxidant defenses after prolonged starvation in Dentex dentex liver, Comparative Biochem Physiology, Part C, 2004, 139: 153 - 156.

[10] IM Mourad and NA Noor, Aspartame (a widely used artificial sweetener) and oxidative stress in the rat cerebral cortex, Int $J$ Biomed Sci, 2011, 2(1), 4-10.

[11] S Marklund and G Marklund, Invovement of the superoxide anion radical in the autoxidation of pyrogallol and a convenient assay for superoxide dismutase, Eur J Biochem, 1974, 47: 469-474.

[12] AK Sinha, Colorimetric assay of catalase, Anal Biochem, 1972, 47: 389-394.

[13] JT Rotruck, AL Pope, HE Ganther, AB Swanson, DG Hafeman and WG Hockstra, Selenium: Biochemical role as a component of glutathione peroxidase, Science, 1973, 179: 588-590.

[14] GE Staal, J Visser and C Veeger, Purification and properties of glutathione reductase of human erythrocytes, Biochem Biophys Acta, 1969, 185: 39-48

[15] A Arjuman, V Nair, HN Gopalakrishna and M Nandini, Evaluation of the antioxidant potential of NR-ANX-C (a polyherbal formulation) and its individual constituents in reversing haloperidol-induced catalepsy in mice, Indian J Pharmacol, Vol 39, Issue 3, 2007, 151-154.

[16] RC Bray, SA Cockle, EM Fielden, PB Roberts, G Rotilio and L Calabrese, Reduction and inactivation of superoxide dismutase by hydrogen peroxide, Biochem J, 139, 1974, 43-48.

[17] KA Amin, HA Hameid and AHA Elsttar, Effect of Food Azo Dyes Tartrazine and Carmoisine on Biochemical Parameter Related to Renal, Hepatic Function and Oxidative Stress Biomarkers in Young Male Rats, Food and Chemical Technology 48 (2010) 2994-2999.

[18] Y Gao,C Li, J Shen, H Yin, X An and H Jin, Effect of food azo dye tartrazine on learning and memory functions in mice and rats and the possible mechanisms involved, Journal of Food Science, Vol 76, Issue 6, T125-T129, August 2011.

[19] MM El-Tohamy, The mechanisms by which oxidative stress and free radical damage produces male infertility, Life Science Journal, 2012; 9(1), 674-88.

[20] M Friederich, P Hanselland F Palm, Diabetes, oxidative stress, nitric oxide and mitochondria function, Curr Diabetes Rev 2009 5:120-144.

[21] H Kaneto, N Katakami, M Matsuhisa and T Matsuoka, Role of reactive oxygen species in the progressin of type 2 diabetes and atherosclerosis, Mediators of Inflammation, Volume 2010, Article ID 453892, 11 pages.

[22] SC Sikka, Relative impact of oxidative stress on male reproductive function, Curr Med Chem. 2001; 8:851-862

[23] P Pathak and U Kapil, Role of trace elements zinc, copper and magnesium during pregnancy and its outcome, Indian J Pediatr 2004: 71:1003-1005.

[24] OG Arinola, JA Olaniyi and MO Akiibinu, Evaluation of antioxidant levels and trace element status in Nigerian sickle cell disease patients with Plasmodium parasitaemia, Pak J Nutr 7(6): 766-769.

[25] DR Ellis and DE Salt, Plants, selenium and human health, Current Opinions in Plant Biology 6: 273-279, 2003.

[26] NI Ward, KA Soulsbury and VH Zeittel, The influence of the chemical additive tartrazine on the zinc status of hyperactive children - A double-blind placebo-controlled study, J Nutr Med, 1:51-57, 1990.

[27] TE Tourmaa, The adverse effects of food additives on health: a review of the literature with special emphasis on childhood hyperactivity, Journal of Orthomolecular Medicine, Vol. 9, No. 4, 1994.

[28] RS MacDonald, The role of zinc in growth and cell proliferation, Journal of Nutrition, 130:1500S-1508S, 2000.

[29] OB Smith and OO Akinbamijo, Micronutrients and reproduction in farm animals. Animal Reproduction Science. 60-61:549560.2000

[30] LR McDowell, G Valle, LX Rojas and J Velásquez-Pereira, Importancia de la suplementación mineral completa en lareproducción de vacas. In: XXXIII Reunión nacional de investigación pecuaria, XXIII Simposium de ganadería tropical: Interacción nutrición-reproducción en ganado bovino, 3-8 November 1997, Veracruz, México. pp. 31-47.

[31] KO Soetan, CO Olaiya and OE Oyewole, The importance of mineral elements for humans, domestic animals and plants: A review, African Journal of Food Science Vol. 4(5) pp. 200-222, May 2010.

[32] N Wiernsperger and JR Rapin, Trace elements in glucometabolic disorders: an update, Diabetology \& Metabolic Syndrome, 2010, 2:70

[33] B Halliwell, Oxidants and human disease: some new concepts, FASEB J, 1: 358-364; 1987.

[34] JG Alvarez and BT Storey, Differential incorporation of fatty acids into and peroxidative loss of fatty acids from phospholipids of human spermatozoa, Mol Reprod Dev. 1995;42:334-346.

[35] RK Sharma and Agarwal, Role of reactive oxygen species in male infertility (Review), Urology. 1996; 48:835-850

[36] D Wilde, Influence of macro and micro minerals in the peri-parturient period on fertility in dairy cattle. Animal Reproduction Science. 96:240-249, 2006.

[37] S Chan, B Gerson and S Subramaniam, The role of copper, molybdenum, selenium, and zinc in nutrition and health, Clinics in Laboratory Medicine, 1998, 18:673-685.

[38] N Mehedi, S Ainad-Tabet, N Mokrane, S Addou, C Zaoui, O Kheroua and D Saidi, Reproductive Toxicology of Tartrazine (FD and C Yellow No. 5) in Swiss Albino Mice, American Journal of Pharmacology and Toxicology 4 (4): 130-135, 2009. 